\title{
Key Meanings Transmitted by the Names of Russian Newspapers and Magazines of the Soviet Era (1917 - 1991)
}

\author{
Lyli R. Muhametzanova, Leyla A. Mardieva
}

\begin{abstract}
The article analyzes the names of newspapers and magazines published in the Republic of Tatarstan (a constituent entity of the Russian Federation) from 1917 to 1991. The research object (hemeronyms) is considered by the authors as an artifact of culture; the authors prove that among all the onyms, hemeronyms seem to be the most dependent on cultural, historical, and ideological factors. Based on the application of the methods of keywords and key meanings, the semantic field of the media onomastic regional space of the studied period is reconstructed. It is shown that the nuclear idea of a semantic field constructed as a result of systematization of empirical material is an idea that can be designated as "building a society of a new formation". The nuclear idea is revealed in specific key meanings: "struggle" (namely 'active actions to overcome or achieve something' and 'active actions aimed at achieving labor success'), "renewal", i.e. 'aimed at building a new socio-economic formation - the communist', "path", "collectivization", "labor as the supreme value", "guiding the role of the communist party (communists)". The research results obtained by the authors reflect the specifics of not only the regional (Tatarstan) media onomastic space, but also the whole of Soviet Russia. The algorithm of the study of Russian hemonyms of the Soviet era presented in the work can be extrapolated to the similar material of other national-cultural formations or of the Russian one, but covering other time periods with its own specific worldview dominant.
\end{abstract}

Keywords: names of newspapers and magazines, onomastic media space, ideology and language, keywords, key meanings.

\section{INTRODUCTION}

A distinctive feature of the names of newspapers and magazines (hemeronyms) is their, perhaps, greater than that of other onyms, their dependence on the cultural and historical traditions and ideological guidelines that dominate the given historical period of the development of society. This is illustrated by the active renaming of Russian periodicals of the late XX century, caused by the desire of publishers to replace ideologically labeled lexical units in the name of the media with neutral ones, such as "Put Iliicha" (1965) "Vysokogorskie vesti" (1994); "Stalinskii put" (1937) "Novaia Kama" (1962); "Krasnyi Zai" (1938) - "Novyi Zai" (1995); "Maiak kommunizma" (1961) - "Kaybitskie zori" (1993), "Zaria komunizma" (1958) - "Sheshminskaia nov" (1984) and many others.

The area of our attention is primarily the ideological conditionality of the name of newspapers and magazines, and in this regard, the hemionym of the Soviet era (1917-1991) are of undoubted interest.

The research file consists of 431 names of newspapers and magazines published in the territory of the modern Republic of Tatarstan (subject of the Russian Federation), 383 of which are the names of newspapers and 48 - magazines.

\section{METHODS}

This work was carried out in the spirit of research on media and political linguistics [Lewin-Jones et al. 2013; Adams, Michael 2013; Anikin et al. 2015; Gizatullina et al. 2017; Muhametzyanova et al. 2017; Shkurko et al. 2018; Pakdel, \& Talebbeydokhti, 2018; Melo, et al 2018; Kasteyeva, 2018].

The main method for studying hemonyms is the "keywords" method [Vezhbitskaia 2001: Ayebo, \& Mrutu, 2019]. A. Vezhbitskaia uses it to identify specific features of national cultures; we used it to determine the distinctive features of one cultural community (Russian) in the Soviet era of its development. The work, however, takes into account the fact that ideas relevant to public consciousness are translated not only with the help of words and that the decisive factor in the actualization of certain semantic units is not the form of linguistic units but their function [Maidanova et al. 2004: 7]. The foregoing predetermined the appeal to the term "key meanings" and the corresponding research method [Maidanova et al. 2004; Mukhametzianova, Mardieva 2018].

\section{RESULTS}

From 1917 to 1991 in Russia there was a rapid increase in the circulation of newspapers and magazines. And this is no coincidence. The print media was considered the party's ideological weapon, a means of propagating Marxist-Leninist ideology. According to official ideology, "the transition from capitalism to socialism occurs as a result of the struggle of the working class, whose historical mission is the revolutionary conquest of political power, with the goal of destroying all exploitation of man by man and building communism. <... ... The Communist Party is the vanguard of the working class, its organizer and leader" [Philosophical 1987: 259]. This definition already contains the following key meanings: the struggle for freedom and the "bright future"; the guiding role of the proletariat and communists in this struggle. We shall consider how these and other ideas are revealed in hemeronyms. 


\section{DISCUSSION}

The key meaning is "struggle".

It is It is implemented by words and phrases with meanings 'active actions to overcome something or to achieve the desired results'. Typically, this idea is represented by the following keywords:

- struggle (newspaper "Borba", 1936);

- assault (newspapers "Za shturm", "Na shturm", 1930, "Mekhovshchik na shturme", 1932, "Stalinets na shturme", 1931);

- attack (newspaper "Ataka", 1931);

- terror (newspaper "Krasnyi terror", 1918);

- revolution (newspaper "Znamia revoliutsii”, 1917; magazines "Puti revoliutsii", 1922; “Za kulturnuiu revoliutsiiu", 1931).

It is interesting to note the change in the evaluative component in the semantics of the word revolution. With a common seme 'coup', dictionaries of the XIX and XX centuries record diametrically opposed semes with an estimated component: "unrest", "rebellion", "sedition", "violent" [Dal 1935, 4: 89] and "leading to a transition from a historically obsolete social system to a more progressive one" [Dictionary of 1988, 3: 693].

The idea of struggle is also updated with the help of keywords such as:

- krasnyi (red) "referring to revolutionary activity" and krasnoarmeets (a Red Army soldier), see newspaper names: "Krasnaia Tatariia", 1929, "Krasnyi Put", 1922, "Krasnyi Zai”, 1938, "Krasnoe znamia”, 1938, "Krasnyi medik", 1935, "Krasnyi potovod", 1936, "Krasnyi tekstilshchik", 1935; magazines: "Krasnye zori" 1919, "Krasnyi terror", 1918, "Zhurnal ranenogo i bolnogo krasnoarmeitsa" (1920), etc.;

- znamia (banner). This polysemous word, of course, was semantized in a hemonym both as 'worldview, guiding idea' and as a book and rhetorical 'embodiment of unity of a group fighting for something'. The polysemantics of the word banner gives rise to many interpretations of hemonyms, which include this lexical unit. The universality of the meaning of the word znamia determines its particular relevance in the onymic media space of the analyzed era, for example: "Znamia revoliutsii”, 1917; "Znamia truda", 1917; "Znamia", 1955, 2006; "Znamia Lenina”, 1931; "Krasnoe znamia”, 1938; "Znamia komunny", 1938; "Znamia sotsializma”, 1941; "Znamia pobedy", 1959; "Znamia kommunisma", 1982, "Stalinskoe znamia", 1952; "Kolkhoznoe znamia", 1954; "Leninskoe znamia", etc.

- pobeda (victory) - 'success in the struggle': "K novym pobedam", 1936; "Znamia pobedy", 1945; "Put pobedy", 1953

\section{The key meaning is "struggle as a competition".}

The idea of struggle for the Soviet state was always relevant. In the era of industrialization and later, the idea of struggle is modified, the struggle begins to mean not confrontation but competition. The goal of the struggle-contest is the speedy building of a society of a new formation. This meaning of the word was presented by:

- borba (struggle) - 'active actions aimed at achieving labor success': "Borba za kachestvo", 1933;

- boi (battle) - 'competition aimed at fulfilling obligations', boevoi (combat) - 'aimed at competition': "V boi za finplan", 1932 “Za boevuiu uchebu”, 1934;
- derivatives of the word udarnichestvo - 'competition for increasing labor productivity' - udarnik - 'advanced worker', udarnyi: "Finansovyi udarnik», 1936; «Golos udarnika», 1947; «Klich udarnika», 1936; «Udarnik», 1931; «Za udarnye tempy», 1932; «Za udarnyi trud», 1977; «Udarnik sotsialisticheskikh polei», 1932; «Udarnik sotsialisticheskogo zhivotnovodstva», 1933, etc.;

- stakhanovets - 'the worker who achieves the highest labor productivity': «Golos stakhanovtsa», 1937; «Stakhanovets transporta», 1938; «Stakhanovskii reid», 1939;

- piatiletka - 'a plan for the development of the national economy of the USSR': «Za piatiletku», 1935; «Za vtoruiu piatiletku», 1962;

- uskoreniye, tempy, vysokii, sorevnovanie: «Za uskorenie», 1987; «Za bolshevistskie tempy», 1932; «Za vysokii urozhai», 1934; «Za udarnye tempy», 1941; «Kolkhoznoe sorevnovanie», 1953.

The key meaning is "renewal", namely 'aimed at building a new socio-economic formation - the communist'. Representatives of this meaning are the keywords:

- novyy, for example, names of newspapers: «Novaia derevnia», 1929; «Novaia zhizn», 1963; «Novyi Sarman», 1964; «Novyi Zai», 1973, magazines: «Novoe delo», 1922; «Novaia derevnia», 1924; «Novyi put», 1944, etc.;

- zarya in the meaning of 'beginning, origin', see, for example, names of newspapers: «Zaria», 1958, 1965; «Zaria kommunizma», 1958, 1962, magazines: «Krasnye zori», 1919, etc.;

- bolshevistskiyi: «Za bolshevistskiyii transport», 1932; «Za bolshevistskie tempy», 1932, 1934; «Za bolshevistskii kolkhoz», 1933, 1936; «Za bolshevistskii kauchuk», 1933; «Bolshevistskii put», 1935; «Za bolshevistskii kolkhoz», 1935; «Za bolshevistskii sovkhoz», 1935;

- sovetskii, for example, names of newspapers: «Za sovetskii kauchuk», 1933; «Sovetskaia kinoplenka», 1933; «Sovetskii medik», 1950; «Sovetskaia Tatariia», 1951; «Sovetskoe khoziaistvo», 1960; magazines: «Vestnik sovetskoi iustitsii ATSSR», 1923;

- kommunizm, kommunisticheskii, for example, names of newspapers: «Za kommunizm», 1929; «Znamia kommunizma», 1938; «Put' kommunizma», 1953; «K kommunizmu», 1962; «Maiak kommunizma», 1961; «Stroitel kommunizma», 1961; «Za kommunisticheskoe prosveshchenie», 1962; magazine: «Kommunisticheskii put», 1921.

The keyword pravda (truth) is closely related to the idea of renewal as indicated above, indicating the purpose of renewal - to achieve truth, see newspaper names: «Politotdelskaya pravda», 1934; «Kolkhoznaia pravda», 1935; «Stalinskaia pravda», 1938; «Zavodskaia pravda», 1959; «Zelenodolskaia pravda», 1960; «Leninskaia pravda», 1965, etc.;

The key meaning is "put" (path). It is actualized with the help of the same-name keyword, which in the context of heimeonyms and in the extralinguistic context of the era is interpreted as 'movement to change the present situation', see, for example, the newspaper: «Krasnyi put», 1922; «Kolkhoznyi put», 1932; «Bolshevistskii put», 1935; «Novyi put», 1944; «Put Oktyabria», 1970; «Svetlyi put», 1976; magazines «Puti revoliutsii», 1922 ; «Put Iliicha», 1925; «Nash put», 1926, etc., as well as lexeme maiak: «Maiak», 1963, 1966, 1966; «Maiak kommunizma», 1961. 
The key meaning is "the organizing and guiding role of the Communist Party and the Communists (Bolsheviks)". This meaning is conveyed by the words:

- bolshevik and its derivatives: newspapers «Bolshevichka», 1933, «Bolshevik», 1934, «Kamskii bolshevik», 1936, «Bolshevistskii put», 1935, «Bolshevistskii transport», 1994; magazine «Bolshevik Tatarii», 1935;

- kommunist: newspapers «Slovo kommunista», 1993, magazines: «Kommunist Tatarii», 1920, «Molodoi kommunist», 1920.

Since the 30s of the XX century, the idea of the guiding role of the Communists in the process of building a new society is personified. In onomastic media space there is a high degree of activity of hemonyms with the names Lenin (Ilyich), Stalin and their derivatives, for example, in the names:

- newspapers «Znamia Lenina», 1931; «Leninets» 1929, 1940, 1964, 1962; «Put Lenina», 1935; «Leninskii put», 1935, 1936, 1945, 1962, 1968; «Po leninskomu puti», 1936, 1945, 1965; «Leninskoe znamia», 1954; «Po Leninskomu puti», 1954; «Leninskaia pravda», 1940, 1965, as well as «Zavety Iliicha», 1955; «Put Iliicha», 1965; magazines «Na putiakh leninizma», 1928, etc.;

- newspapers «Stalinets na shturme», 1931; «Stalinskiy put», 1937; «Stalinskaiya pravda», 1938; «Stalinets», 1931, 1936 (Laishevsky district), 1936 (Novo-Pismyansky r-onregion), 1954; «Stalinskii marshrut», 1937; «Stalinskii put», 1938; «Stalinskii prizyv», 1939; «Za Stalinskii urozhai», 1938, 1941; «Stalinskoe znamiya», 1952 (Laishevsky region); 1952 (city of Chistopol), 1953, 1956; «Po stalinskomu puti», 1939, 1953, «Put Stalina», 1940, etc.

The key meaning is "hegemony of the working class". According to Marxist-Leninist ideology, a special historical mission is assigned to the working class, since it was recognized as the driving force of the "revolutionary process of transition from capitalism to socialism" [Philosophical 1986: 397], see also a seme 'being the leading force of society' in the definition of the word rabochii (worker) in the dictionary [Dictionary 1988, 3: 576]. Accordingly, we assumed that hemeronyms should convey the key meaning of "working class hegemony". However, research material can hardly unambiguously confirm this hypothesis. In total, our file contains 6 hemeronyms with a noun rabochii («Chistopolskiy rabochii», 1947; «Rabochii KamAZa», 1973; «Rabochii stroiindustrii», 1982, etc.) and 6 with an adjective rabochiy (newspapers «Rabochee slovo», 1959; «Rabochaia chest», 1977; magazines: «Rabochee delo», 1917; «Rabochaia zhizn», 1919, etc.). The meaning "hegemony of the working class" and, accordingly, the seme "being the leading force of society" is to some extent implemented in the names "Rabochee slovo", "Rabochaia tribuna", as well as in the name of the newspaper "Zavodskaia tribuna", 1968. In all the rest cases mentioned above, the seme is neutralized.

The key meaning is "collectivization".

The following keywords are the guides of the idea of organizing large masses of people into one whole:

- kolkhoz, kolkhoznik, kolkhoznyy, see names of newspapers: «Kolkhoznik Tatarii», 1930; «Shagai v kolkhoz», 1930; «Kolkhoznik», 1930; «Krepim kolkhozy», 1932; «Kolkhoznyi put», 1932, 1934; «Klich kolkhoza», 1936; «Kolkhoznyi trud», 1956, etc.;

- kommuna: newspapers «Prikamskaia kommuna», 1931; «Kommuna», 1956.
The key meaning is "work as the highest value".

The overall employment in the Soviet state was the key to justice: labor guaranteed social security in old age, equal pay for men and women, etc. The word trud (labor) as a value takes on a symbolic meaning in the era of socialism (see, for example, proverbs and sayings: He who does not work neither shall he eat; Will and labor give marvelous seedlings, Whoever is the first in labor, glory to him everywhere, etc.). The considered meaning is implemented by the key word labor, see, for example, the names of the newspapers «Znamia truda», 1917,1954; «Slava trudu», 1966; «Za udarnyi trud», 1977 and magazines «Vestnik truda i narodnogo khoziaystva TSSR», 1918, etc.

\section{V.SUMMARY AND CONCLUSIONS}

Since the Soviet state not only openly declared its ideological principles but also conducted active work to introduce them to the masses, including through newspapers and magazines, the names of printed periodicals of the Soviet Republic are fairly well systematized. The key meanings identified in the course of the analysis, translated by the hemonyms of a given era, can be represented as a semantic field. The nuclear component of this field is the idea of "building a society of a new formation". The designated nuclear component of the semantic field is revealed in private key senses: "struggle" ("active actions to overcome something", "active actions to achieve the desired results" and later: "active actions aimed at achieving labor success", "competition, aimed at fulfilling labor obligations"), "renewal" ("aimed at building a new socio-economic formation - communist"), "path", "collectivization", "labor as the highest value", "organizing and directing the role of the Communist Party (Communists / Bolsheviks)".

The study proves the ideological motivation of the names of newspapers and magazines of the Soviet period of development of Russian society, demonstrates the productivity of the use of the keyword method and the method of key meanings to establish the specificity of hemeroyms of the Soviet Republic, the possibility of using these methods for further onomastic research in diachronic and sociolinguistic aspects.

\section{ACKNOWLEDGMENTS}

The work is performed according to the Russian Government Program of Competitive Growth of Kazan Federal University.

\section{REFERENCES}

1. Vezhbitskaya A. Understanding of cultures through the use of keywords. M.: Languages of Slavic culture, 2001. 288 p.

2. Maidanova L.M., Solomatov S.I., Fedotovskikh T.G., Chudinov A.P. The word and key meanings in modern media texts. Ekaterinburg: Publishing House of Ural University, 2004. 229 p.

3. Muhametzanova L.R., Mardieva L.A. The titles of newspapers and magazines of the Kazan governorate: lexico-semantic analysis'// Modern Journal of Language Teaching Methods. Vol. 8, Issue 11, November 2018. Pp.118 - 122.

4. Lewin-Jones, Jenny; Webb, Mike. Ideology in Disguise: Place Name Metonyms and the Discourse of Newspaper Headlines // SOCIOLOGICAL RESEARCH ONLINE. 2013. Vol. 18 Issue 4 Article Number: 18 Published: NOV 29

5. Adams, Michael. The American Blade: Etymologies of a Newspaper Name // Names-a 
journal of onomastics. 2013. Vol. 61. Issue: 3 Pp. 140-149.

6. Anikin E.E., Budaev E.V., Chudinov A.P.

7. Historical Dynamics of Metaphoric Systems in Russian Political Communication// Voprosy Kognitivnoy Lingvistiki. 2015. № 3 (44). P. 26-32

8. Gizatullina, A., Gumerova M., Vinogradova T., Grachev M. Post-Perestroika Ideologemes Survey (Based on the Newspaper "Izvestiya”)// Helix, 2017. Vol. 8(1). Pp. 2270 - 2274.

9. Muhametzyanova L. R., Mardieva L. A., Elena S. Kara-Murza. Name of the newspaper: communicative-functional approach // National Academy of Managerial Staff of Culture and Arts. 2017. № 4 (2). Pp. $90-93$.

10. Shkurko V. Ju., Mardieva L.A., Shchuklina T. Yu., Chudinov A. P. Poster images in a new linguistic and extralinguistic context// Amazonia Investiga. 2018. Vol. 7, Núm. 12 (2018). 320-324.

11. Philosophical Dictionary / Ed. I.T. Frolov. M.: Publishing house of political literature, 1986. $590 \mathrm{p}$.

12. Dahl V. Explanatory Dictionary of the Great Russian Language: in 4 volumes, V. 4. St. Petersburg, Moscow, 1882. 704 p.

13. Dictionary of the Russian language: in 4 volumes / Academy of Sciences of the USSR, Institute of Russian language; Ed. A.P. Evgenieva. V.4. 3rd ed., stereotyped. M.: Russian language, 1988. 800 p.

14. Pakdel, M., \& Talebbeydokhti, A. The Effect of Adjustment Announcement of Predicted Profit on Price and Trading Volume of Listed Companies in Tehran Stock Exchange. Dutch Journal of Finance and Management, 2(1), (2018). 49. https://doi.org/10.29333/djfm/5825

15. Melo, R., Sobrinho, V. D. P. F. M., Filho, I. J. D. M., Feliciano, F., \& Maciel, P. R. M. Redundancy Mechanisms Applied in Video Streaming Service on Eucalyptus Cloud Computing Infrastructures. Journal of Information Systems Engineering \& Management, 3(3), (2018). 25.

16. Ayebo, A., \& Mrutu, A. An Exploration of Calculus Students' Beliefs about Mathematics. International Electronic Journal of Mathematics Education, 14(2), 385-392. https://doi.org/10.29333/iejme/5728

17. Kasteyeva, M. Belgium priority as a partner for the Republic of Kazakhstan. Opción, 34(85-2), (2018). 752-772. 